\title{
LA HISTORIA DEL SIGLO XIX DESDE LA PERSPECTIVA MODERADA: REFLEXIONES DE ANTONIO ALCAJÁ GALIANO SOBRE ESPAÑA.
}

por

\author{
RAQUEL SÁNCHEZ GARCÍA \\ Universidad Complutense (Madrid)
}

RESUMEN: Antonio Alcalá Galiano (1789-1865), destacado intelectual del partido moderado, ofreció con sus escritos acerca de la bistoria de España y del pensamiento en Europa, una de las perspectivas conservadoras más lúcidas desde la que observar el pasado más próximo. Pero además, sus artículos, discursos y libros no sólo se ciñen al análisis politico, sino que también muestran su preacupación por las cuestiones más puramente metodológicas. Entre éstas ultimas, destacan la implicación del bistoriador en su trabajo, la utilización crítica de las fuentes o su concepción global de la bistoria como bistoria de la civilización. Por lo que respecta a los aspectos politicas de su análissis, Alcalá Galiano se interesó especialmente por los traumáticos años previos a la implantación del gobierno representativo en España, las manifestaciones de particularismo y los fenómenos revolucionarios.

Palabras clave: Historiografía. Historia de España. Pensamiento político. Liberalismo. Partido moderado.

ABSTRACT: Antonio Alcala Galiano (1789-1865), well-known thinker and politician of the conservative party, offered one of the most lucid conservative perspectives on the recent past in bis writings on Spanish bistory and European thought. Moreover, bis articles, papers, speeches and books not only analyze political affairs, but also show bis interest in methodological questions. The bistorian's involvement in bis work, the critical use of sources, and his bolistic idea of bistory as the bistory of civilization are the most conpicuous of these metbodological questions. With regard to political appects, Alcala Galiano was particularly interented in the traumatic years before the introduction of nepresentative govemment in Spain, manifestations of paricularism and revolutions.

KEY WORDS: Historiography. Spanish history. Political thinking. Liberalism. Partido moderado.

Hispania, LX/1, núm. 204 (2000) 289-314 
En el mundo de la política del siglo XIX español pocos hombres dispusieron del suficiente tiempo como para poder elaborar una consistente interpretación del quehacer humano, una sólida reflexión acerca de la historia reciente. Pese a todo, y aunque predominaron otro tipo de obras (más vinculadas al lado pragmático de la gestión pública), nos han quedado algunas muestras de la decidida voluntad de llevar a cabo un análisis del pasado con vistas a entender el presente y construir el futuro. Entre esos intentos destacó la obra de reflexión historiográfica de Antonio Alcalá Galiano (1789-1865), quien habiendo abandonado el radicalismo puramente verbal de su juventud, retornó a la política como teórico destacado del partido moderado. Formó parte Galiano de esa generación de hombres públicos que, al igual que Angel Saavedra, Eugenio Aviraneta o Javier Istúriz, tuvieron la ventaja de ser testigos presenciales (y en ocasiones protagonistas) de los hechos históricos más significativos del siglo en que vivieron. El enorme interés de su contribución viene, por tanto, avalado por su propia experiencia vital tanto o más que por la profundidad de sus reflexiones.

\section{ALCALÁ GALIANO Y LA HISTORIA.}

El ingreso de Antonio Alcalá Galiano en la Real Academia de la Historia puso la guinda institucional a una vida llena de interés por el acontecer humano, por el estudio de la expansión en el tiempo de los afanes de los individuos. Fue propuesto por los académicos Quadrado Delgado, Fort y Vicente de la Fuente (17-III-1863) para ocupar el sillón que el fallecimiento del conde de Canga Argüelles había dejado deshabitado. El 24 de abril resultó definitivamente elegido, celebrándose la toma de posesión el 26 de diciembre del año de 1864. Se dio la circunstancia de que al ser Alcalá ministro de Fomento en aquella época, y por tanto jefe de las Academias, tuvo que presidir la primera parte de la sesión, para después traspasar el puesto al director de la R.A.H.*, don Antonio Benavides, mientras que él pronunciaba su discurso de ingreso sobre las antiguas Cortes Españolas'.

Sin ser un historiador vinculado a ninguna institución, salvo en esta última etapa de su vida, y sin tener el menor afán de convertirse en un científico de la historia al uso, que en aquel entonces comenzaba a implantarse también en nuestro país, Alcalá manifestó desde los primeros momentos de su vida un cre-

* R.A.H.: Real Academia de la Historia.

R.A.H., Expediente de don Antonio Alcalá Galiano y Fernández de Villavicencio, y Discursos Leídos ante La Real Academia de la Historia en la recepción pública del Excmo. Sr. don Antonio Alcalá Galiano el 26 de diciembre de 1864, Madrid, Academia de la Historia (Imprenta de José Rodríguez). Puede leerse también el artículo de DE LA VALGOMA, D.: "Alcalá Galiano y el Duque de Rivas en la Real Academia de la Historian: Boletin de la Real Academia de la Historia, tomo CLVII, cuaderno II, (1965), pp. 197-212. Alcalá Galiano fue nombrado ministro de Fomento en el gobierno narvaísta de 1864́, tarea ésta que sería su más dramárica y última acrividad política. 
ciente interés por los hechos del pasado nacional y extranjero (en particular inglés y francés). Escribió artículos, tradujo libros y se dedicó a la crítica de obras históricas de gran prestigio en su momento como la del Conde de Toreno y la de Thiers. Si por algo ha sido célebre, es por sus textos' autobiográficos, especialmente sus Memorias y Recuerdos de un anciano, pero también por otros documentos menores como los Apuntes para la biografía del excelentísimo señor don Antonio Alcalá Galiano, Apuntes para servir a la bistoria del origen y alzamiento del ejército destinado a Ultramar en 1 de enero de 1820, o las Canciones patrióticas desde 1808 a 1814, $y$ desde 1820 a 1823. La vinculación entre las Memorias y los Recuerdos es muy estrecha, ambos relatan épocas similares, pero sin embargo los segundos resultan ser más bellos estilísticamente, pues fueron revisados por el autor antes de su muerte para la publicación como artículos breves en la revista La América. Años después, Antonio Alcalá Galiano, hijo, recopilaría todos aquellos recuerdos en forma de libro y los daría a la imprenta. Las Memorias, más farragosas y detallistas, fueron el grueso y la base de lo escrito por nuestro autor para configurar el fundamento de su legado autobiográfico a la posteridad. Su repentina muerte impidió una revisión final que corrigiera errores y apreciaciones. Sin embargo, y dado el interés que podían ofrecer a un público, el de la Restauración monárquica, cada vez más intrigado por los primeros años del siglo, el hijo de Alcalá logró la ayuda de su primo el Conde de Casa Valencia, Emilio Alcalá Galiano, para dar a la luz las Memorias en 1886 , las cuales ya eran conocidas en pequeños retazos por haber sido divulgadas en el periódico El Día. Datan las Memorias de 1847-1849, y su propósito era explicar los acontecimientos de la vida del autor desde su nacimiento hasta el final del Trienio liberal en 1823. Del mismo periodo se ocupan los Recuerdos, aunque éstos incluyen dos capítulos dedicados a la emigración sumamente evocadores de lo que ha sido en España la tragedia del disidente político².

Pese al encanto de ambas obras, no hay que acercarse a ellas buscando el estudio histórico, pues la pretensión del autor al escribirlas no era tal. Galiano quería justificar por medio de sus escritos autobiográficos una trayectoria política que había evolucionado desde un liberalismo de salón, aparentemente radical, hasta un conservadurismo moderado. En los años en que Alcalá escribió las Memorias se estaba produciendo en su vida intelectual un proceso de asentamiento de las ideas políticas elaboradas en la emigración y teorizadas en el Ateneo, por lo que todas las páginas escritas tienen como objetivo presentarle como un hombre razonable frente a la imagen de incoherencia que proyectaba al exterior. La misma actitud cabe encontrar en tantos otros periodistas y hombres políticos del XIX, los cuales, metidos a historiadores, se acercan al pasado

2 Los Recuerdos datan de 1862. Alcalá Galiano se vio movido a redactarlos a ráz de la publicación en el diario Las Novedades (11-VII-1862) de las sesiones de las Cortes de Sevilla de 1823 en las que se pedía la destitución ternporal de Fernando VII. Galiano, protagonista de los sucesos, decidió explicar a sus contemporáneos su actuación y la situación política de la España del primer tercio del siglo.

Hispania, LX/1, núm. 204 (2000) 289-314 
reciente con una intención muy distinta de la que mantenían los antiguos cronistas, y desde una perspectiva conscientemente parcial para realizar lo que se ha llamado una historia pragmática ${ }^{3}$. Por otro lado, esa propia justificación de la acción del personaje es la mejor prueba del espíritu de una centuria que nació con la reivindicación del individuo y su especificidad, característica ésta de las más loables que haya podido aportar el siglo XIX. Alcalá no se resigna a que la imagen que de él quede sea unilateral y trata de definirse frente al exterior, de presentarse a si mismo ante una posteridad desconocida:

"Voy a referir los sucesos de mi vida, con los cuales están eslabonados muchos de los más importantes de mi patria. Razón ésta última que me disculpará en alguna manera de la nota de presuntuoso que justamente se me podría poner por el hecho de ocupar la atención pública en negocios de mi pobre persona, pues con la grandeza de un objeto quedará compensada la pequeñez suma del otro, con él tan audazmente apareado. Bien que tampoco se debe extrañar que algo diga de mí propio, cuando tanto, y no en mi honra, han dicho y dicen varios escritores; pareciendo muy justo que, si bien de chica estatura moral o intelectual, pero levantado sobre un pedestal enorme, habiéndome dado a conocer en grado superior al de mis merecimientos, quiera manifestarme tal cual soy, o cual me creo yo mismo, y no según me pinta la malquerencia de mis contrarios o la equivocación de otros a quienes éstos alucinan. Razón hay para que defienda un hombre a quien agravian, para que se sincere un sujeto al cual hacen cargos completamente injustos muchos, abultados otros, y unos pocos si justos, de los que admiten disculpa»4.

Desde sus escritos autobiográficos Alcalá Galiano no trataba de explicar su evolución personal en un sentido íntimo, según una concepción personal de la reivindicación romántica del individuo, sino vincularse a lo público, hacerse partícipe de lo colectivo desde la propia individualidad, aportar lo particular a un proyecto común que, en el caso de España, era la implantación de un sistema de gobierno liberal, en un sentido amplio. De este modo, Galiano tiene como objetivo presentar sus vivencias personales, sus apreciaciones de los hechos desde el punto de vista de quien ha participado de lleno en ellos, y así, Julián Marías le calificó con todo acierto como «...el historiador desde dentro, el primer hombre que en España hizo historia política general partiendo de sus propias acciones y pasiones" $"$. Desde luego, la preocupación por la imparciali-

\footnotetext{
3 LEFEBVRE, G.: El nacimiento de la historiografia moderna, Barcelona 1985, p. 171. Ese sentido instrumental de la historia ya había empezado a apuntarse con las transformaciones sociales del siglo anterior (Maravall, J. A.: «Mentalidad burguesa e idea de historia en el pensamiento español», en Estudios de la bistoria del pensamiento español (siglo XVIII), Madrid 1991, p. 117).

4 Alcala Galiano, A.: Memorias de D. Antonio Alcalá Galiano, publicadas por su bijo, en Obras escogidas, Madrid 1955, vol, 1, p. 255.

5 Marıas, J.: Meditaciones sobre la saciedad española, Madrid 1968, p. 102.
} 
dad, tan frecuente entre los historiadores decimonónicos, también está presente en Alcalá, pero en él no es asunto primordial:

"Que la historia debe ser imparcial, nadie lo niega. Que lo sea historia alguna es muy dificil, porque la imparcialidad es ajena o poco menos, de la condición humana, y para ser cabal y perfectamente imparcial sería forzoso no amar ni aborrecer, y mirar con rostro igualmente sereno, y sangre igualmente templada y regular en la circulación, al amigo y al contrario, al pariente y al extraño, al compatricio y al extranjero, a nuestra religión y patria, y a naciones y religiones no sólo diferentes de las nuestras sino a veces hasta enemigas. Lograda tal imparcialidad, se habría perdido para conseguirla todo afecto noble y todo pensamiento levantado ${ }^{6}$.

Las traducciones constituyeron otro capítulo importante en el acercamiento a la historia por parte de Alcalá. Muy conocida en su tiempo era la obra de Samuel Astley Dunham History of Spain and Portugal, de manera que se hizo necesaria traducirla al español, tarea de la que se encargó nuestro autor. La obra apareció en 1846 con el título de Historia de España desde los tiempos primitivos basta la mayoría de la Reina doña Isabel $I \Gamma$. Constaba de siete volúmenes, de los cuales los cinco primeros correspondían a la traducción de la obra inglesa (con añadiduras y comentarios del intérprete español) y los dos últimos procedían de la mano de Alcalá. Sin embargo, los argumentos de ambos, el autor y el traductor, están tan entretejidos, que con frecuencia no es posible distinguir dónde terminar la labor de uno y empieza la del otro. Esto es particularmente notable a partir de los capítulos dedicados a la España de los Austrias, momento éste que Alcalá no deja escapar para infiltrar sus comentarios acerca de la que constituía su gran preocupación en aquellos años: el proceso de formación del estado español. Aunque sobre eso se tratará con más detenimiento, puede señalarse ahora que para Alcalá tal proceso es, sobre todo, un producto de la modernidad, pues, y por supuesto teniendo en cuenta las tradiciones, la edad media presentada como ejemplo de libertades, no es más que un mito elaborado por los autores posteriores, entre los que él coloca, en lugar destacado, a Martínez Marina. Las críticas a Dunham se centran especialmente en la censura que el inglés hace de la obra del padre Mariana, cuya Historia de España fue, hasta la publicación de la de Modesto Lafuente en 1850, punto de referencia básico para todo aquél que se sintiera intrigado por las gestas nacionales ${ }^{8}$. Galiano, manifestando una aguda capacidad para contextualizar las cosas, señala-

6 Alcala Galiano, A.: "De la historia y del modo de escribirla", en La América, vol. VI, 24VII-1862, p. 9.

7 Revista de Europa, 1846, pp. 250-252. El título completo de la obra era Historia de España desde los tiempos primitivos basta La mayorta de la Reina doña Isabel II, redactada y anotada con arreglo a la que escribió en ingless el doctor Dunbam, por D. Antonio Alcalá Galiano, con una reseña de los bistoriadores de más nota, por Don Juan Donoso Cortés y discurso sobre la bistoria de nuestra nación, por D. Francisco Martinez de la Rosa, Imprenta de la Sociedad Literaria y Tipográfica, Madrid 1846.

8 CIRUjANO, P.: y otros, Historiografia y nacionalismo español, 1834-1868, Madrid 1985, p. 82. 
ba que había que tener en cuenta las circunstancias en que se escribió la obra del padre Mariana, quien si bien pecaba de un limitado sentido crítico, en parte por la censura y en parte por las carencias de la ciencia histórica de los siglos XVI y XVII, había representado en su momento un considerable hito en relación a otros contemporáneos en lo que se refiere a estilo y composición?.

La Histoire du Consulat et de l'Empire de Thiers fue la segunda traducción ${ }^{10}, \mathrm{y}$ en el análisis de la obra puso Galiano gran interés por cuanto consideraba que Thiers había manipulado los hechos, especialmente en relación a España. Sus críticas al historiador francés aparecieron en la prensa a medida que los numerosos volúmenes se iban publicando. Aunque su versión no pasó del tomo noveno, las Historias, sobre todo Histoire de la Révolution Française, de Thiers tuvieron otros traductores (Pedro de Madrazo, Antonio Ferrer del Río...), por lo que el acceso a sus comentarios fue relativamente fácil. Alcalá Galiano tenía una idea premeditada acerca de la labor del traductor. Desde su punto de vista, éste no cumplía su misión trasladando únicamente las palabras de un idioma a otro, sino que estaba obligado a aclatar conceptos o a desmentir falsas afirmaciones, pues si bien se podía suponer la competencia del autor de la obra, no debían dejarse de lado los posibles errores de apreciación propios de quien no conoce la realidad más que desde su perspectiva. Entendía Alcalá la tarea del traductor, por tanto, como una labor participativa y sobre todo críticall. Éste es el principal sentido que tenían sus ataques a Thiers, a quien acusaba de haber consultado muy pocos autores extranjeros a la hora de elaborar su Historia, lo que había dado como resultado una obra tremendamente parcial e incluso inverosímil por patriotera: «Así es que, aquí, donde quiera que habla de una función de guerra o una refriega, siempre mueren menos franceses que enemigos, siempre llevan éstos lo mejor en todo encuentro, sin que pueda adivinarse cómo al cabo viene a perder la batalla» ${ }^{12}$. La parcialidad, inevitable en la mayoría de las ocasiones, había caído en la exageración en el caso de Thiers, quien, habiéndose presentado como un defensor de la libertad, había ido transformándose a lo largo de su obra en un defensor del Emperador, abrumado y maravillado por la gloria que éste aportó a la historia de Francia.

Las críticas forman el tercer gran bloque de las contribuciones de Alcalá Galiano al mundo de la historiografía. Junto a las ya citadas a la obra de Thiers, escribió nuestro protagonista numerosos comentarios de libros aparecidos en su momento o en los años inmediatamente anteriores entre los que des-

9 Alcala Galiano, A.: Historia de España, Madrid 1844, vol. I, p. 137.

10 El Laberinto, vol. 2, Madrid 1845, p. 208. Apareció con el título de «Historia del Consulado y del Imperio de Napoleón, por Mr. Thiers, traducida, corregida y aumentada por don Antonio Alcalá Galiano".

"1 Alcala Galinno, A.: «Sobre la Historia del Consulado y del Imperio de Napoleón, por Mr. Thiers», en Crónica de ambos mundos, tomo 1, 1860, p. 71.

12 Alcala Galiano, A.: «De los tres últimos tomos de la Historia del Consulado y del Imperio de Napoleón, por Mr. Thiers", en La América, vol. VI, 12-XII-1862, p. 6. 
tacan los publicados en relación a la obra de lord Macaulay y la historia británica y en particular la que escribió para glosar la Historia del levantamiento, guerra y revolución de España del conde de Toreno ${ }^{13}$. Esta reseña tiene el interés de que nos acerca a lo que después se analizará más detalladamente sobre la concepción de Galiano de la historia y del modo de trabajar con los acontecimientos, testigos del pasado. En sus críticas, mantiene un frío análisis global de la obra desde la perspectiva historiográfica, pero también contempla otros aspectos como son el tratamiento del lenguaje, las formas de expresión, la vinculación del autor con el tema tratado (con vistas a determinar su grado de parcialidad) y sobre todo, la comparación del estudio citado con un conocimiento bastante exhaustivo de la producción historiográfica en lo que se refiere a hechos relativamente cercanos en el tiempo (en particular, la Revolución Francesa y el Imperio, y la guerra de España contra los franceses a principios de siglo). Las reseñas de Galiano buscan sobre todo la reflexión acerca de los hechos narrados, reflexión nacida de la comprensión conjunta de los fenómenos, y ahí estriba la principal censura que hace a la Historia del conde de Toreno: «Desearíamos que hubiese dicho algo el historiador respecto al estado político, intelectual y moral de España en los días en que su narración comienza». Teniendo en cuenta que el ensayista fue activo personaje en el teatro de los acontecimientos, tal petición no resulta descabellada, plantea Alcalá, siendo conocedor del temor de Toreno de resultar excesivamente parcial. En este sentido, hay que destacar que resulta bastante singular la ecuanimidad con que ambos, autor y crítico, contemplaron los hechos, ecuanimidad que, por cierto, huyó de la pluma del antiguo orador de la Fontana al recordar con entusiasmo los lejanos tiempos del Trienio en su comentario de otra publicación contemporánea, el Viaje a Cádiz en 1823 por un miliciano nacional de Madrid ${ }^{14}$. La valoración general del libro del conde de Toreno es positiva, teniendo especial peso en la balanza el estilo del autor, pues según la concepción que tiene Alcalá de la obra histórica, ésta debe saber unir la profundidad a la amenidad en un combinado cuya receta se encuentra en este párrafo que augura posteriores comentarios al respecto:

13 El primer tomo de la obra del conde de Toreno apareció en Madrid en 1835. Las reseñas de Alcalá se publicaron en la Revista Española los días 13 y 14 de julio de 1835 , y en la Revista de Madrid, 1844, tomo III, actualmence pueden encontrarse en las Obras escogidas, vol. 2, pp. 446-457. Galiano se lamentaría en la necrológica del Conde por el escaso interés que los conternporáneos habían prestado a esta obra en El Heraldo, 6-X-1843. La crítica a la obra de Macaulay apareció con el título de «Del célebre escrizor inglés Lord Macaulay y de su Historia de lnglaterra», en la Crónica de Ambor Mundos, vol. 1, 1860, pp. 215-218.

14 Fernandez, A.S.: Viaje a Cádiz en 1823, por un miliciano nacional de Madrid, Madrid 1835, AlCAlA Galiano, A.: Obras..., vol. 2, pp. 457-459 (reseña publicada inicialmente en la Revista Española, 5-VIII-I835). Aun en la emoción del recuerdo, Alcalá no se olvidaba de lanzar sus dardos: "Quien desee empaparse en memorias tiernas y respetables, compre el Viaje a Cádiz en 1823. No aprenderá mucho; leerá un itinerario o poco más; pero sentirá no poco y serán buenas las sensaciones».

Hipania, LX/1, núm. $204(2000) 289-314$ 


\begin{abstract}
«Por cierto, en el método que ha adoptado y sigue el señor Conde de Toreno, descuella sobre manera, siendo en la narración animado; en las reflexiones unas veces maduro, y otras sutil, y siempre ingenioso; en la averiguación de los hechos, diligente; en las relaciones, exacto; en los juicios, bastante imparcial; en la pintura de los caracteres, diestrísimo y juntamente fiel retratista, compitiendo lo brioso del pincel con lo semejante de las copias o los originales trasladados; en el estilo, elocuentemente nervioso; y hasta en las arideces y menudencias de ciertas noticias de varios y continuos (pero poco grandes combates), casi en todas las ocasiones, entretenidom 15 .
\end{abstract}

\title{
LA HISTORIA COMO SABER GLOBAL.
}

"Son las buenas historias obras de arte...". Con esta frase Alcalá pretendía aproximarse a una concepción de la obra histórica conjuntamente, es decir, que abarcase las distintas manifestaciones de la actuación humana en sentido temporal. La historia como compendio de realizaciones humanas: hechos políticos y batallas, pero también literatura y arte, filosofía y estética, unidas en el devenir del tiempo; una idea de la historia como civilización. Por supuesto, no hay que buscar en Galiano un análisis de las transformaciones económicas de la sociedad en el sentido en que actualmente entendemos el estudio histórico, aunque sí entran en su esquema los profundos movimientos sociales que se estaban produciendo en su época, pues su historia, mejor dicho, su concepción de ella, camina con interés creciente hacia la investigación del hombre, tanto en su acción colectiva como en sus manifestaciones individuales. Alcalá considera que analiza la historia cuando escribe de literatura o de política, pues su manera de acercarse a estas cuestiones sigue siempre un trayecto retrospectivo, buscando los orígenes de conceptos, de situaciones, de ideas, para enlazar pasado y presente, en una noción continuada, sin rupturas de la producción ideológica del individuo. Particularmente notable e ilustrativo resulta, en esta especie de genealogía de los conceptos que lleva a cabo nuestro autor, el análisis de lo político, centro principal de sus preocupaciones. La combinación de elementos de la historia, la linguística, la sociología y la literatura a la hora de establecer los orígenes y las diversas aplicaciones de términos como «liberal» $\mathrm{y}$ «liberalismo» o "revolución», que veremos en su momento, ofrecen frutos muy interesantes en el terreno del análisis social. De este modo, Galiano no desprecia ningún instrumento que le pueda servir para captar el carácter de un momento histórico, incluso demanda valorizar el testimonio de los mitos como representaciones ideológicas de los puntos de referencia de cada sociedad, en una suerte de historia de las mentalidades:

15 Alcala Gallano, A.: «Hiscoria del levantamiento, guerra y revolución de España, por el conde de Torenom, en Obras..., vol. 2, p. 453.

Hispanic, LX/1, núm. 204 (2000) 289-\$14 
«Pero, si los mitos merecen ser desechados en la historia de los sucesos y en el juicio de los caracteres de personas famosas, son acreedores, por otra parte, a set atendidos y respetados en la historia de la ideas. Al tratar de las pasadas edades, no basta saber lo que en ellas se hacía, es forzoso conocer lo que en ellas se pensaba. Personajes hay de pura invención, de los cuales nadie pretende que sean otra cosa, y cuyo influjo en los pensamientos y afectos de sus contemporáneos y sucesores no es inferior al que han tenido y aun tienen personas que verdaderamente han existido»16.

Pero la captación global no se queda en la pluralidad temática, sino que ha de abarcar también la variedad interpretativa. En esa línea se dispararon sus críticas a la Historia de Thiers, y en esta línea se decanta su propia actividad como investigador cuando se propone el acercamiento a algún tema histórico, en una búsqueda infatigable de la veracidad (que no de la imparcialidad, pues «Que un historiador contemporáneo sea enteramente imparcial es cosa imposiblem).

El gran interés que Alcalá Galiano muestra por el método para escribir la historia se deriva por un lado, desde luego, de su preocupación científica, pero, por otra parte, también hay un elemento, casi diríamos que fundamental, y es el valor de la historia para el hombre contemporáneo. Sin quitar mérito al estudio de épocas remotas en el tiempo, Galiano prefiere la investigación en la historia más reciente, a la que llama contemporánea, un estudio del que se puedan sacar consecuencias para la vida de los hombres que son directos herederos de ese pasado cercano. Se trata, en definitiva, de comprender la propia época mediante el análisis de la que le dio origen, de buscar las causas de los actuales problemas en su génesis. La idea que tiene Alcalá de la historia se asemeja mucho en este aspecto a la de Hume en el sentido de considerar la historia como un arma de enseñanza moral por el estudio de las acciones de los hombres, un arma mucho más eficaz, por basarse en hechos reales, que la que pueda ofrecer cualquier filosofía abstracta o cualquier compendio de ética redentora. Tal forma de entender el saber histórico se fue acrecentando en él con el paso de los años, a medida que fue comprobando cómo suelen tener más trascendencia las acciones humanas concretas que los grandes programas de transformación moral o social. El diplomático Augusto Conte recordaba en sus memorias unas palabras de Galiano a este respecto que aclaran cuáles debían ser las intenciones de todo aquél que se acerque a la morada de Clío: «Las generalizaciones de la filosofía histórica, solía decirnos a mi y a mis compañeros de estudio, son sin duda, buenas para explicar los sucesos pasados; pero no para adivinar los futuros, y pueden infundir desconfianza en la virtud de la voluntad de los hombres. Para neutralizar, pues, los malos efectos de esas generalizaciones, les aconsejo a ustedes que se dediquen mucho al estudio de la historia

16 Alcala Galiano, A.: “De los mythos", en La América, vol. VI, 24-VI-1862, p. 8. 
misma. En la historia verán ustedes lo que valen los caracteres y cómo se sobreponen a todas las circunstancias y a todas las evoluciones más temibles» ${ }^{17}$.

Hablando del método en la historia, Alcalá recordaba frecuentemente la sentencia de Quintiliano «Scribitur ad narrandum, non ad probandum» que Barante colocó al inicio de su Historia de los duques de Borgoña de la Casa de Valois: 1364-1843, y que constituyó el lema de su quehacer historiográfico: la historia ha de ser narración de los hechos, simple recuento de acontecimientos y nunca una reflexión sobre ellos. Galiano, que si algo buscaba en la historia era precisamente la reflexión, analizó la trascendencia de seguir un método u otro, limitarse a narrar o buscar la explicación de los hechos y su trascendencia. Repasando la evolución de la historiografía a lo largo del tiempo, Alcalá se planteaba las limitaciones de sus intereses, pues ocupándose tan sólo de «eminentes capitanes o repúblicos», la historia perdía la amplitud de su valer al quedar cercenada su aplicación a las grandes batallas o hechos políticos; echaba en falta nuestro autor en la literatura histórica antigua y medieval «lo que llamamos hoy filosofía de la historia». Dejando aparte a Vico (a quien pone como ejemplo de gran autor poco atendido por la pesadez de su estilo ${ }^{18}$ ) no es hasta el siglo XVIII cuando la historiografía se desarrolla sobre otras bases. Si bien se sitúa en Francia el lugar donde tiene un auge considerable la historia veteada de reflexión, nuestro protagonista se decanta sin dudarlo por los historiadores ingleses Robertson, Gibbon y Hume (sobre todo por los dos últimos), ya que éstos unen con singular acierto la erudición (especialmente notable en el caso de Gibbon), el análisis y la claridad de juicio. Junto a ellos, mantenía Alcalá admiración por otros historiadores británicos, en especial por los llamados "philosophic historians» (Ferguson y Tytler), los cuales, desde una perspectiva totalmente alejada de la francesa sobre la presunción de la perfectibilidad continuada del hombre, que en Gran Bretaña se encarnó en Hartley y en Godwin, buscaban el origen de la sociedad y sus instituciones y comprendian la acción de los individuos en persecución de sus propios fines e intereses (lo que llamaron «heterogeneity of ends» ${ }^{19}$ ). Es, sin embargo, en el siglo XIX cuando se produce la gran transformación metodológica en el terreno de la historiografía. El desarrollo del sentido crítico representará esa gran baza que los historiadores

17 CONTE, A.: Recuerdos de un diplomático, Madrid 1901, vol. 1, p. 107.

I8 «...Vico, cuya Scienza nuova es hoy tenida en no corto precio; obra de la cual lo poco agradable del estilo atajó el camino a la fama hasta entonces entre sus propios paisanos», A. Alcalá Galiano, «De la historia y del modo de escribirla», en La América, vol. VI, 24-VII-1862, p. 8.

19 Culler, A.D.: The Victorian mirror of bistory, Londres 1985, p. 22. La lección decimotercera de su Historia de la literatura está dedicada precisamente a los historiadores británicos. Pese a la admiración que les profesa, Galiano no puede evitar disentir de Hume y Gibbon en la pintura que éstos hacen de la degeneración del Imperio Romano con la llegada del cristianismo. Desde su perspectiva conservadora y católica, Alcalá encuentra en el principio cristiano la semilla de la cultura europea que ha germinado en una revalorizada Edad Media. Lejos de ser una época oscurantista y pobre, la Edad Media representa el punto germinal de los principios de la modernidad. 
románticos pueden oponer a sus colegas del pasado ${ }^{20}$; a partir del siglo XIX Alcalá pone de manifiesto que «toda historia debe ser filosófica y política» para que tenga algún valor y alguna repercusión en su tiempo. Los hombres buscan en ella una guía, una herramienta de trabajo en un siglo eminentemente científico. La historia abandonará ahora el campo de las artes para insertarse de lleno en el de las ciencias de la sociedad. El énfasis en la importancia del sentido crítico implicaba una diferente concepción del trabajo del historiador: ya no era un narrador, ya no podía aceptar la historia «ad narrandum», sino que el historiador estaba obligado a escribir "ad probandum".

«Los buenos autores que hoy viven y en época poco lejana han vivido, y los críticos que con agudeza y tino han juzgado sus obras, se distinguen de las generaciones anteriores en cuanto tratan de hermanar con las consideraciones filosóficas a que comenzó a entregarse el siglo XVIII, la erudición y la diligencia que llevan a averiguar prolijamente la verdad de los hechos, buscándola en testimonios contemporáneos o poco menos, juntando éstos y cotejándolos unos con otros, y no sólo haciendo contar la verdad de cada cual, o la autenticidad de los documentos que los confirman, sino buscando la interpretación que puede dárseles con arreglo a los tiempos, usos y costumbres y hábitos de pensamiento y sentir de las personas de esta o esa otra época; por donde viene a realizarse el consorcio del criterio filosófico y la fidelidad escrupulosa» 21 .

Con estas palabras Alcalá Galiano exponía sus experiencias con respecto al quehacer histórico, reflexionando sobre el valor de una tarea compleja y con una importante proyección en la sociedad, al menos en el siglo anterior. En otro lugar, afirmaba que lo que distinguía los historiadores de su tiempo era precisamente ese afán por buscar noticias fidedignas y de ellas extraer conclusiones válidas para esa época, sin grandes pretensiones moralizantes, sin querer abarcar una comprensión total de la naturaleza humana, pues cada historiador escribe para su tiempo, para sus contemporáneos, desde una similar perspectiva y buscando unas enseñanzas aplicables a los problemas existentes en ese mo-

20 AlCala Galiano, A.: Historia de la literatura española, francesa, inglesa e italiana en el siglo XVII, Madrid 1845, p. 466. En este sentido, Alcalá admiraba especialmente las obras del historiador de la literarura François Villemain, a quien confesó seguir en las clases que sobre la misma materia dictó en el Ateneo.

21 alcala Galiano, A.: "Antigua constitución política de Castilla», Discurso de ingreso en la R.A.H. (26-XII-1864), p. 4. «...se ha hecho indispensable consultar a la par las narraciones de los autores, o tesrigos de los hechos, los documentos de cada época y, con los áridos y a veces poco sinceros documentos de oficio, otros donde los hombres se descubren y, o se retratan a si mismo, o pintan a los que tienen delante; correspondencias, memorias escritas cuando exisren; en suma, todo cuanto puede traer edades pasadas a la vista del presente. Agrégase a esto la interpretación hecha de los actos y dichos humanos con arreglo a lo que se pensaba y sentía en la época cuyas cosas se cuentan, en vez de fundar el juicio conforme a ideas, doctrinas y acciones de épocas posteriores, y sobre todo, de la que el historiador vive y ha formado su criterio del presente», «De la historia y del modo de escribirla», en La América, vol. VI, 24-VH-1862, p. 9. 
mento. El convencimiento del valor de hacer historia, del importante significado de reflexionar sobre el pasado desde el presente y en función del futuro, refleja un nuevo talante en el espíritu de unos hombres que se sabían protagonistas en esa tarea de reconstrucción que ellos pretendían científica. Uno de los más brillantes historiadores franceses, François Guizot, ponía en palabras ese talante: «Nous sommes appelés à considérer, à faire marcher ensemble la science et la realité, la théorie et la pratique, le droit et le fait. Jusqu'à notre temps, ces deux puissances suivre des routes diverses, sans se connaître, sans se rencontrer du moins $»^{22}$. En efecto, esa anhelada confluencia entre realidad y ciencia había comenzado a producirse en el terreno de la historiografía decimonónica, primero de la mano de la escuela histórica alemana y ayudada después por la llamada escuela francesa. A ellas se unieron las diversas tradiciones nacionales para crear una disciplina de carácter acumulativo y crítico y con una clara función social. El papel del liberalismo clásico en esta tarea es, no hay ni que decirlo, fundamental: el valor social del conocimiento histórico alcanzó en tal ambiente intelectual un prestigio máximo y contribuyó a analizar, comprender y en última instancia legitimar las prácticas políticas de la representación limitada, la soberanía compartida y el gobierno mixto ${ }^{23}$.

La contemporaneidad de la reflexión del historiador queda plenamente probada, afirma Alcalá, con uno de los caracteres fundamentales de la historiografía decimonónica: la inclusión de un nuevo protagonista del devenir histórico, el pueblo. «Lo que sí debe diferenciar a los historiadores de nuestros días de los de tiempos antiguos es que deben atender, como muchos de ellos atienden, a las cosas de los pueblos, tanto cuanto a las proezas de los guerreros y a los actos y conducta de los políticos; a las particularidades de la vida y de la sociedad, igualmente que a los actos de los gobiernos; al estado de las letras, de las artes, aun de las de inferior clase, y a los usos y hábitos de la sociedad alta, media y baja, no menos que a los grandes acontecimientos, que tienen un influjo, si más visible, acaso no superior en la suerte de los estados» ${ }^{24}$. De nuevo vuelve a hacer hincapié en la comprensión global del estudio de la sociedad y de sus manifestaciones a la que ya hicimos referencia, y dentro de la cual sitúa como precedentes a Voltaire (a quien, por otra parte, no aprecia demasiado como historiador) y a lord Macaulay, el gran cantor de las glorias liberales e industriales de Inglaterra y portavoz de la interpretación whig de la historia. Lo más destacable de ese análisis es justamente esa incidencia en el papel del pueblo como necesario protagonista histórico, en especial en la época contemporánea, pueblo manifestado en clases medias y altas, burguesas en definitiva, ejes cardinales de las historias del siglo XIX, pero también en clases bajas, actrices

22 GuIzoT, F.: Cours d'bistoite moderne. Histoire genérale de la civilisation en Europe, París 1829, 4a lección, 9-V-1829, p. 3.

23 Pasamar Alzursa, G.: «La invención del método hiscórico y la historia metódica en el siglo XIX", en Historia Contemporánea (U.P.V.), n 11, (1994), p. 186.

24 AlCala Galiano, A.: “De la historia...”, p. 9. 
principales de los grandes movimientos sociales del siglo. Si los grandes han dejado de ser el único centro de atención y nuevos personajes aparecen en el drama, también entre el público se han producido variaciones y esos nuevos lectores de la historia quieren verse retratados en el gran cuadro. Fue sobre todo a partir de la revolución de 1848 cuando se desarrolló con más fuerza ese afán por precisar el lugar en la historia de los desconocidos habitantes de ciudades y pueblos que habían sorprendido a todos los importantes por su presencia activa en la política ${ }^{25}$. Será ésta una historia hecha de impresiones, una acumulación de los afanes de muchos, que si de cerca no permite tener conciencia clara de la realidad, de lejos, con la ayuda del historiador, ofrece una más nítida contemplación que cualquier relato basado en la vida de algún ilustre personaje.

Precisamente por el interés en lo colectivo nace en Alcalá una auténtica obsesión por el individuo y su papel en la historia. Aunque empapado de resabios estamentales, es un hombre de su tiempo, y sus ambiciones aristocráticas se trasladan de los linajes familiares (de los que por supuesto carece) a las glorias propias. La figura romántica del hombre como moderno Prometeo está siempre presente en los escritores del siglo XIX, el hombre como creador de su propio destino, lo que si por un lado es una apelación a la singularidad, también es un medio por el que las clases medias (trasuntos sociales idealizados del héroe) justifican con autosatisfacción muy burguesa su ascenso imparable. En el caso de Galiano, no se trata tanto de adular a las clases medias como a si mismo. Si en casi todos sus escritos hay un algo de repercusión de sus obsesiones psicológicas en lo que respecta a encontrar un papel en el mundo por el propio valer, en el caso de los textos en los que se hace referencia a distintos personajes de la historia, esta característica aparece aún de forma más notable. Con una especial agudeza para la caracterización espiritual y moral, las obras de Alcalá llamaron la atención de sus contemporáneos precisamente por esa capacidad. Cuando apareció la Historia de España en 1846, el crítico Luis Page señalaba que la obra «versa especialmente sobre delineaciones de caracteres de los hombres que han figurado por distintos conceptos, mereciendo un nombre más o menos esclarecido" ${ }^{26}$. El interés por el individuo y su capacidad para enfrentarse al destino fue el centro del mensaje ya mencionado que Conte recogía para sus memorias. De ahí que Alcalá mantuviese tan cerrada oposición a Thiers y a su compatriota Mignet, historiadores de la llamada escuela fatalista, tan admirada por Martínez de la Rosa ${ }^{27}$. En un artículo que escribió en 1838 analizando la figura de Robespierre se puede observar esto con más claridad que en ningún otro de sus escritos. La agudeza con que penetra en la persona-

2s GOOCH, G.P.: Historia e bistoriadores del siglo XIX, México 1942, p. 570.

26 Revista de Europa, 1846, p. 251.

27 Más que fatalistas habría que denominatlos deterministas (LefebVRE, G.: op. cit., p.173). Sobre los historiadores franceses de este periodo, WaLCH, J.: Let matitres de l'histoire, 1815-1850: Augustin Tbierry, Mignet, Guizot, Thiers, Micbelet, E. Quinet, Ginebra 1986. 
lidad del gran jacobino y la capacidad de ver más allá de lo que la imagen exterior ha proyectado de él, son realmente sorprendentes y reflejan un especial talento para estudiar a los hombres. Alababa Galiano en Robespierte la habilidad para hacerse un lugar en la palestra de las cabezas revolucionarias: «...pues si Robespierre no era un talento portentoso, fue hombre que se ganó por sus fuerzas propias el alto puesto en que llegó a colocarse, y no se ganan sin un mérito sobresaliente puestos semejantes disputados por rivales numerosos, y de ellos muchos insignes en ingenio, ciencia y osadía ${ }^{28}$. La admiración hacia la valía personal no impedía a Galiano censurar las aficiones sanguinarias del Incorruptible, encontrando en su tipo de personalidad grandes peligros, pues "por tener semejanza con la virtud es más funesta a la sociedad». Sin embargo, su brillante capacidad para evaluar a los hombres se dejaba ofuscar en ocasiones, tal fue el caso en el juicio que emitió de Napoleón al escribir sobre la Historia de Thiers. Napoleón, "el hombre más grande desde César", como le llamaba Stendhal, no representaba para Alcalá más que un ambicioso, con talento, pero sin escrúpulos. Obviamente, la intervención del Emperador en los sucesos de España impedía a Galiano verlo desde otra perspectiva que no fuera la del recelo, pese a que él fue el primero en sufrir las consecuencias del reintegro del inepto Fernando VII al trono. Resulta curioso contemplar cómo los pensadores del siglo XIX no franceses se resisten a la hora de evaluar positivamente la figura del gran Napoleón. Tratando de sustraerse a la fascinación del personaje, intentan rebelarse a duras penas, y no pueden evitar, como le sucedió a Carlyle en su última conferencia sobre el héroe moderno, hablar de él llamándole «nuestro último gran hombre». También escribió Alcalá varios retazos biográficos de ilustres españoles como Jovellanos o Argüelles, en los que predomina el mismo interés indagatorio acerca de sus tareas en el mundo y de la peculiaridad personal de cada uno, sin embargo, la finura psicológica con la que nuestro autor estudió a Robespierre llega posiblemente más lejos que el análisis de sus coetáneos, ámbito éste en el que le hubiera resultado más difícil por pura y simple proximidad vital.

\section{LAS REVOLUCIONES Y LA TRANSFORMACIÓN DE LA SOCIEDAD.}

Pocos hechos históricos atrajeron tanto la atención de Alcalá Galiano como la revolución francesa. Por si misma, y por las consecuencias que tuvo para España, la gran revolución constituyó para nuestro autor un tema recurrente

28 Alcala Galiano, A.: “Maximiliano Robespierre», en Revista de Madrid, 1838, tomo 1, p. 230. Este interés psicológico por el individuo y sus capacidades formó parte del «estudio filosófico de las humanidades» que demandaba Alberto Lista a sus alumnos y que tenía por objeto desarrollar tanto el sentido crítico como el autoconocimiento. Sobre esta cuestión puede leerse el breve pero interesante libro de GARRIDO PALAzON, M.: La filosoffa de las Bellas Letras y la bistoria literaria en España (1777-1844), Almería 1992. 
en sus estudios. Profundo conocedor de las publicaciones surgidas al socaire de tal interés, el fenómeno se convirtió para él en objeto de reflexión abstracta, en una suerte de análisis acerca del significado de los cambios violentos en el devenir de los pueblos. El impacto de la revolución fue brutal en su momento e incluso más tarde, pues como dijera Lamartine, nunca tantos y tan trágicos acontecimientos se sucedieron agrupados en tan corto espacio de tiempo. España se vio arrasada por una invasión exterior y cerró sus puertas a cualquier aire francés, por muy oxigenante que éste pareciese, por lo que la conmoción de las antiguas estructuras sociales y políticas duró todo un siglo en lugar de haberse trastocado en breves años, evitando no pocas muertes y guerras.

La debilidad y el temor que mostró Alcalá al observar la revolución de 1848 no le impidió hacer interesantes observaciones sobre el carácter de los hechos revolucionatios. Si bien sus miedos conservadores lo empujaban al orden, en una concepción de la historia como desarrollo fluido de los acontecimientos, en un progresivo proceso de ajuste en la sociedad entre lo antiguo y lo nuevo, no podía dejar de contemplar las transformaciones bruscas como necesarios resortes para acompasar los movimientos de las dos grandes fuerzas creadoras de la historia: el gobierno y la sociedad. La atención a las manifestaciones de la opinión pública, a la evolución de los tiempos y una clara conciencia de las líneas de actuación por parte del poder (en lo que se refiere a la defensa de determinados intereses, siempre vinculados a lo que llama la sociedad, que en realidad es una concreta clase social), constituyen los medios por los cuales pueden evitar los estallidos violentos. Por exceso o por defecto en la acción del poder, las revoluciones conducen, al menos en sus primeros momentos, al despotismo: «Dos clases de gobiernos absolutos amenazan a Europa; el uno llamándose monárquico o de orden, el otro llevando diferentes nombres, de los cuales el que le compete donde quiera es el de revolucionarion' ${ }^{29}$.

Sin embargo, cuando el ajuste no se ha producido, la irrupción de las nuevas fuerzas se produce inevitablemente $y \mathrm{da}$ pie a un proceso difícilmente calificable, en el que nada hay definido, en el que distintos caminos se ofrecen, $y$ en el que la violencia asusta por ser el único arma eficaz para hacerse con el poder. La sociedad deslavazada, desintegrada en sus distintos componentes, va a la deriva durante un período de caos, justamente la época más peligrosa pues ninguna apelación a la sensatez tiene lugar: lo existente ha perdido su legitimidad y lo nuevo aún está naciendo ${ }^{30}$. Así, afirma Alcalá, entró Francia en un

29 ALCALA Galiano, A.: Breves reflexiones sobre la indole de la crisis por que están pasando los gobiernos $y$ pueblos de Europa, Madrid 1848, p. 62.

${ }_{30}$ «Un hombre, que en medio de la inquierud $y$ agitación crece en fuerza, granjeándose el favor público, acaba por sobreponerse a los bandos entre si contendientes, y usa del poder inmenso que lo revuelto de los tiempos le ha dado para poner las cosas en paz, sosiego y orden, gobernando ya con severidad, ya con misericordia, pero siempre con dureza, aplandido al fin de la gente pacífica y acomodada porque les asegura vivir en tranquilidad...", ALCALA GalinNo, A.: Leccioner de derecho politico, Madrid 1984, p. 334.

Hiqpania, LX/1, núm. 204 (2000) 289-314 
tiempo de barbarie, en el que «los franceses sólo atendían a la causa pública y en su delirio sólo obraban de un modo violento y feroz». Pese a todo, y precisamente por la natural tendencia del ser humano a vivir con cierta seguridad, se despertó en el común del pueblo una oleada de cordura que demandaba el final del desastre, que buscaba una salida del oscuro túnel de la irracionalidad ( Pero en medio de todo esto, el entendimiento humano no había caído en un letargo precursor de la muerte...»). La catarsis llevada a cabo por la Revolución es valorada por Alcalá positivamente: «Pero, señores, por lo que sirvió esta época terrible a la suerte intelectual de los hombres, siéndoles a la larga provechosa, fue por las saludables reflexiones y reacciones de que fue madre», pues la limpieza del aire enrarecido por la corrupción y la cerrazón borbónicas dio paso a un nuevo tiempo: «Nació una mudanza en los pensamientos; volverse los ánimos a las fuentes de lo grande y de lo bello, esto es, a los principios morales y religiosos "31. Resulta interesante observar cómo Galiano hace hincapié en la existencia de un inmanente "espíritu de resistencia» que es, por un lado cordura y por otro puro y espontáneo humanitarismo («la no menos generosa compasión nacida a la vista de muchas y grandes desgracias y ruinas, así públicas como privadas»). Recoge aquí Alcalá esa tradición de la historiografía inglesa de considerar que al margen de racionales proyectos de transformación, existe en la sociedad una sabiduría innata acerca de sus necesidades, lo que Hume denominaba el instinto de transformación de los procesos histórico-sociales ${ }^{32}$. Esas necesidades se colman con unas relaciones fluidas entre gobierno y sociedad, los cuales establecen comunicación de forma continuada mediante los puentes tendidos por el pensamiento constitucional contemporáneo, por lo que, según la apreciación de Alcalá, se había logrado alcanzar en su época el método más conveniente para la evolución paulatina y sin violencias de las sociedades. Sin embargo, y al contrario que Burke, no mantiene nuestro autor ninguna actitud reverencial hacia el estado, pues admite la justicia de las revoluciones: "Justas llamo a las que provocadas por un acto de injusticia cuya reparación por otras vías que las de la violencia es imposible, no diré obren quebrantando las leyes, pero éstas, quebrantadas habían sido ya...."33. Afirmaciones como ésta le mantienen alejado de las concepciones globalizantes del pensador inglés quien consideraba, casi diríamos que preludiando a Hegel, que cada generación era "un eslabón de la gran cadena del orden eterno". Más próximo a lo terrestre, las ideas de Alcalá con respecto al origen de las revoluciones beben directamente de Benjamin Constant. Para comprobarlo, observemos la simili-

31 Alcala Gallano, A.: Historia de la literatura..., pp. 419-420.

32 MEINECKE, F.: El bistoricismo y su génetis, Madrid 1983, p. 234. Achacaba Alcalá Galiano a las abseracciones de Rousseau el predominio, en las primeras etapas de la Revolución francesa, de las grandes teorías. De Rousseau afirmaba que «no concebía el gobierno popular sino como absoluto o poco menos" ( $D e$ la diversa indole del principio de libertad y del expíritu de revolución, en Memorias de la Real Academia de Ciencias Morales y Politicas, Madrid 1861-1863, tomo 1, p. 399).

33 Alcala Galiano, A.: Lecciones..., p. 329. 
tud de planteamientos en este párrafo escrito por Constant en 1797 con la palabras que Galiano pronunció desde el Ateneo y repitió en multitud de artícuIos: «Para que las instituciones de un pueblo sean estables, deben estar el nivel de sus ideas, entonces no podrá haber jamás revoluciones propiamente dichas, y aunque haya algunos choques y trastornos individuales, algunas mudanzas o partidos, mientras las instituciones permanecen en aquel nivel, ellas subsisten. Pero cuando se destruye al armonía entre unos y otros, las revoluciones son inevitables; éstas concurren a restablecer aquélla; y aunque no es tal el objeto de los revolucionarios, sí lo es, empero, el de las revoluciones» ${ }^{34}$. Nuestro autor traslada al ámbito sociológico lo que para Constant es ideológico, pero el fondo de la argumentación es el mismo.

Al igual que Tocqueville quien, hablando del 48 decía que Ia Revolución Francesa vueive a empezar porque siempre es la misma, Alcalá Galiano estaba convencido de que se había entrado en un proceso imparable; la revolución, con sus ventajas e inconvenientes había roto los tradicionales diques de la legitimidad del poder y se reproduciría siempre que emergiera una fuerza social que fuera lo bastante potente como para lograr arrastrat a los gobiernos. Los hechos de 1848 fueron, desde su perspectiva, un reverdecer de las ideas de 1789 , un resurgimiento que ignoraba el estado de cosas que había proseguido a las grandes violencias, y cuya asamblea «representa, por decirlo del modo más favorable, el movimiento filosófico-político-científico-literario de la ilustración francesa en la parte especulativa. Es pues, su esencia, y son sus trabajos un volver al estado antiguo o revolucionario de una representación nacional divorciada de los intereses sociales» ${ }^{35}$. Si este renacimiento de la ideología nacional constituía, según su parecer, un falseamiento de la moderna composición de la sociedad, el mayor peligro que encerraba no era tanto su capacidad de influencia como los métodos de los que se servía para irrumpir en escena. La inestabilidad se había arraigado en las sociedades contemporáneas, y había que asimilar la circunstancia de que la violencia constituiría un elemento de la política, un participante perenne e inquietante con el que había que contar y del que había que cuidarse. De aquí sus continuas apelaciones a la vigilancia de los gobiernos en pro del mantenimiento del orden. Así, el análisis de las grandes transformaciones de la reciente historia europea permitían sacar una conclusión: «El siglo XVIII destruyó mucho, fundó poco aunque algo, varió casi todo. Al XIX está reservado el carácter de reedificador y de clasificador de las mudanzas hechas en el antecedente ${ }^{36}$. El hombre del siglo XIX había de acos-

34 CONSTANT, B.: Tratado de las reacciones politicas en Curso de politica constitucional, Madrid 1820, vol. 2, p. 279. De este modo, para Constant las revoluciones no son ni positivas ni negativas, sólo nacen de la fuerza de las cosas. Esta explicación sería retomada después por Tocqueville en $E l$ Antiguo Régimen y la Revolución (SANCHEZ-MEJIA, M ${ }^{2} \mathrm{~L}$.: Benjamin Constant y la construcción del liberalismo posrevolucionario, Madrid 1992, p. 93).

35 AlCala GalinNo, A.: Breves reflexiones..., p. 91.

36 Alcala Galinno, A.: Historia de la literatura..., p. 467. 
tumbrarse a vivir en medio del terremoto, inmerso en una oleada de cambios que no parecían tener fin, pero de los que asomaban nuevas tendencias a la vez que otras, las tradiciones, se derrumbaban.

La insurrección de 1808 en España no podía dejar de ser contemplada con atención para quien, interesado en los fenómenos revolucionarios, buscaba una explicación a los eventos que sacudían a Europa. A menudo se preguntaba $\mathrm{Al}$ calá si era posible aplicar el término revolución, en el sentido moderno que le había dado la francesa, a lo sucedido en España, pues si bien revoluciones había habido muchas a lo largo de la historia, la de Francia significó tal conmoción, tal ruptura con un estado de cosas avalado por los siglos, tal choque brutal con la mentalidad tradicional y religiosa, que llevó a nuestro Galiano a hablar de ella como «la época más importante de la historia del mundo". Buscando en los anales del tiempo, creyó encontrar el precedente más inmediato en la Gloriosa, sin embargo, la naturaleza esencialmente institucional de ésta, limitaba su alcance: «La revolución de Inglaterra, mediado el siglo XVII, no produjo el menor efecto en el modo de pensar tocante a principios políticos en otras naciones que la inglesa» ${ }^{37}$. De este modo, Alcalá, partiendo de su definición genérica de la palabra ( En ella trato con el nombre de revoluciones a mudanzas en la forma o el espíritu del gobierno de los estados llevadas a efecto con violencia y resistidas por una parcialidad más o menos numerosa») creyó necesario resaltar el hecho de que la gran revolución contiene a las demás en el terreno de las ideas y de los hechos: «...ya que desde que ella empezó hasta ahora, se ha tenido a menos aplicar el gran nombre de revolución a alteraciones y conmociones de inferior cuantía en que no caían derivados trono no altares, no rodaban por los cadalsos cabezas de reyes y príncipes, ni desaparecían clases enteras como aristas barridas por un huracán, ni mudaba rápida y violentamente de dueños la tierra, ni se sucedían con el ímpetu y frecuencia con que se empujan unas a otras las olas del mat, los hombres a los hombres y los partidos a los partidos; ni quedaba el cuerpo de un estado como molido y reducido a polvo, para que amasado después por mano fuerte y asimismo diestra, recibiese nuevo ser y forma ${ }^{38}$. Los acontecimientos de España, por tanto, no van a tener el carácter demoledor de los descritos anteriormente, desde luego, pero eso no significa que tengan que ser minusvalorados. De hecho, y desde la perspectiva de Alcalá, la clave del siglo XIX español hay que buscarla justamente en aquellos años en los que se mezclan el fanatismo religioso, la ineptitud de la monarquía y los afanes redentores de los liberales, todo ello confluirá en generar unos comportamientos intolerantes y exclusivistas que analizaría en su escrito "De nuestras costumbres políticas", publicado en la Revista de Madrid (1844, tomo III).

\footnotetext{
37 AlCAla Galiano, A.: «Orígenes del liberalismo español», en Obras..., vol. 2, p. 441.

38 AlCala Galiano, A.: Lecciones de derecho politico, p. 328; «Índole de la revolución de España en 1808», en Revista de Madrid, 1839, tomo III, p. 184 (cambièn en Obras..., vol. 2, pp. 307-325).
} 
Bajo la capa de una guerra contra el francés, se ocultaban dos formas de entender España: la tradicional y la moderna, la amante del despotismo y la apasionada de la libertad. Dos proyectos inconciliables, contrapuestos. Desde el inicio del reinado de los Borbones en nuestro país, las ideas de la Ilustración francesa habían comenzado a penetrar por los surcos de nuestro mejores campos intelectuales, ávidos de doctrinas nuevas y reformadas. El afrancesamiento de nuestra cultura y de nuestra vida política no concernía sólo al apellido de la nueva dinastía, sino que también habían quedado bien arraigadas esas ideas que circulaban por Francia y que ponían en cuestión todo lo establecido, si bien con menos peligro. Efectivamente, si en Francia cada vez más personas ponían en tela de juicio la institución monárquica, en España ésta se desautorizaba por si misma «presentándose con harto menos decoro que solía a los ojos de la muchedumbre». Así se afianzó con solidez una corriente de opinión que demandaba un nuevo talante en el gobierno. Pero tanto los renovadores como los ultramontanos, al decir de Galiano, buscaban un culpable (dos, para ser exactos: $\mathrm{M}^{\mathrm{a}}$ Luisa y Godoy) y un mito, dándose la malhadada circunstancia de que para representar ese papel sólo habían un candidato: Fernando VII. La invasión francesa lanzó un manto de disimulo sobre estas diferencias, y las apelaciones a la guerra ocultaron, sólo temporalmente, la verdadera revolución que se cocía por debajo: «Y en medio de tamaña confusión no había discordia ni por asomo, porque sonaba un grito repetido o acogido universalmente con gozo, y el grito era algo largo para un 'viva', pero largo se le hizo o de intento o por mero instinto, porque diciendo más de una cosa comprehendía más de una opinión y deseo. Aludimos a la bien conocida frase de 'Viva el Rey Fernando, la Patria y Religión'» ${ }^{39}$. Por consiguiente, Alcalá nos va a ofrecer una interpretación de los hechos en la que la falta de referencias de los grupos liberales con respecto al que sería futuro rey, los cuales, creyendo ya imposible una vuelta atrás, y sobre todo en atención a la participación de los españoles en la defensa de la institución, consideraban lógica la instalación de un gobierno constitucional. Sin embargo, Fernando VII, consciente de la fuetza social de la que disponía, no se veía obligado a ceder en este terreno: "Así que su situación y a la par su carácter, no permitían al Rey venido como en demanda de su perdida corona, ni aceptar la Constitución de 1812, ni otra alguna presentada como precio de lo que él no podía comprar creyéndolo suyo». Por ello, los hechos acaecidos en España demuestran que nos encontramos ante un inicial proceso revolucionario, con una fuerza «...si no tanta como hubo en Francia, la suficiente para empezar una serie de mudanzas y contiendas que por largos años nos habría de estar causando crueles padecimientos, dilacerándonos para renovarnos: pues no sin agudo e intenso dolor se toca para curatlas y componerlas a las entrañas de las sociedades» ${ }^{40}$. Como consecuencia de todo esto, con la revolución taponada

39 AlCala Galano, A.: «Índole...», p. 202.

to Ibidem, p. 185. 
por una guerca y el lento fluir de los acontecimientos obstaculizado por un infame monarca, la España del siglo XIX se enfangó en atroces guerras civiles: "Y como suele suceder hubo rebeliones, porque hubo tiranía; $y$ vinieron crueldades sobre crueldades, siendo las segundas y sucesivas venganzas, y por eso más naturales aunque no más justas, y cada acto de retribución provocó y aun justificó otro contrario, y así nos vemos en el momento presente, exacerbados los odios, y sin divisarse fin a sus efectos sanguinarios y dañinos, hasta que consiga la postración nacida del cansancio lo que no alcanzan a lograr los consejos de la razón ni los preceptos de la justicia»41. Sin embargo, y por la «force des choses» de la que tanto hablaba Constant, no podía impeditse lo que ya estaba en funcionamiento, un proceso que arrastraba en toda Europa los vestigios de un pasado ya enfermo, casi moribundo, un proceso en el que España, pese a su tendencia al retraimiento, había entrado de lleno sin probabilidad de vuelta atrás. Galiano, tan atento siempre a las corrientes que barrían Europa, lo vio desde el primer momento:

«La revolución española de 1820 a 23 no fue más que una de las faces o periodos de la gran revolución europea que empezó a ser aplicada a España en el movimiento de 1808 , aunque cabalmente emprendido para conservar a la par con la independencia de la antigua monarquía. El reinado de Fernando VII desde 1814 hasta 1820 había querido ser empresa imposible. De diverso modo se emprendió a fines de 1823 la misma obra y no con mejor suceso, siendo como se verá, la segunda restauración en gran parte continuar la revolución vencida, así en lo que de ella copiaba, como en lo que iba preparando para lo venideromí2.

\section{LA ESPAN̂A DE ISABEL II: «SÍNTESIS DE LOS TIEMPOS».}

Los dos últimos volúmenes de la traducción de la obra de Dunham fueron escritos por el propio Alcalá Galiano y en ellos se puede apreciar de nuevo su interés por la historia contemporánea de España. De aquí, y de los artículos que analizando la misma época publicó en diversas revistas, surge su propia concepción de la historia de nuestro país, que si por un lado se encuentra muy cercana a la de otros moderados, no deja por ello de presentar ciertos matices que la hacen interesante para nosotros. El punto central de su pensamiento es el siguiente: «Las formas de gobierno, calificadas de representativo como por antonomasia, introducidas en España en dos épocas anteriores, en esta tercera se han arraigado harto más que en las antiguas" ${ }^{43}$. De este modo, todo su trabajo se proyecta sobre los tiempos en que vivió como plasmación de un prolongado proceso de maduración de determinadas condiciones políticas, un pro-

41 Ibidem, pp. 212-213.

42 Alcala Gallano, A.: Historia de España ..., vol. 7, p. 263.

i3 Ibidem, p. 584.

Hispania, LX/1, núm. 204 (2000) 289-314 
ceso que ha de ser valorado en su justa medida, resaltando la gran importancia que para España ha tenido la definitiva implantación del gobierno representativo y las enormes luchas que esa batalla ha traído consigo. Por consiguiente, en el momento actual (época isabelina), España se encuentra encauzada en un camino de libertades y cualquier ataque a ese conjunto de instituciones y formas políticas supone una agresión a la esencia misma del gobierno representativo y a la monarquía; de ahí su machaconería en insistir una y otra vez en la necesidad perentoria de no permitir ningún tipo de amenaza, ni por el lado tradicionalista, ni por el radical, a lo ya conseguido. Él, como protagonista de los hechos, trata de ofrecer el panorama en que se desarrollaron éstos como un duro campo de batalla en el que se fueron definiendo las posiciones políticas hasta el asentamiento mayoritario de las ideas inherentes al gobierno constitucional. En ese sentido, Alcalá es, una vez más, un conservador. Temeroso del retorno de las oscuras edades del despotismo, del exilio, de las persecuciones y guerras civiles, parece negarse, en otras ocasiones, a aceptar el avance de los tiempos hacia formas más aperturistas de representación política, a darse cuenta de la aparición de nuevos intereses sociales. A modo de enseñanza para las nuevas generaciones, enfoca sus escritos históricos en una línea ejemplificadora, mostrando los peligros tanto de la demagogia como del ultramontanismo, y considera que la etapa central del siglo es el punto de partida para la instalación definitiva en España de unas costumbres políticas que transformen de manera efectiva no sólo las formas de ejercer el poder, sino la misma convivencia civil. Su interpretación se encuadra dentro de lo que Cánovas Sánchez comentó acerca de la consideración moderada de la época isabelina como síntesis de los tiempos, punto de desembarco tras la penosísima travesía del liberalismo español ${ }^{44}$. Como muy acertadamente se ha señalado, no se busca en estas primeras publicaciones de la época moderada ninguna exaltación nacionalista, sino que la preocupación primordial es la defensa de la monarquía constitucional y la organización de un estado administrativamente unitario ${ }^{45}$. El gran logro de su generación, desde la perspectiva de Alcalá, está precisamente ahí.

La unidad de España, por tanto, se da por sentada. Producto de una historia común, entrelazada de luchas políticas y pactos, los reinos de la Península son para Alcalá elementos de un conjunto unitario, pero elementos que mantienen su diversidad, aunque sea necesario armonizar mediante unas leyes comunes (y centralizadoras) las relaciones de los ciudadanos. Así, trata de tender puentes entre la tradición y los requisitos uniformizadores, en lo que a derechos y deberes se refiere, del régimen constitucional. Si bien sus ideas intransigentes con respecto a los fueros vascos se moderaron un poco en el periodo de su exilio en la época de Espartero, para Alcalá el mantenimiento de estos residuos medievales es totalmente incompatible con el estado liberal. Sin embargo no hay

44 Canovas Sanchez, F.: El partido moderado, Madrid 1982, pp. 303-308.

4s JOVER, J. M.8: La civilización española a mediados del siglo XIX, Madrid 1992, p. 144. 
que olvidar, para que pueda apreciarse la ambigüedad en la que se movían unos y otros, que el discurso foral mantuvo una dualidad de posiciones plenamente consciente, al menos hasta la muerte de Fernando VII. Tras 1834, y pese a su aparente oposición con el régimen liberal, el foralismo trató de mantenerse en la escena política, pues al fin y al cabo, los moderados se dieron cuenta de que aceptando en lo posible (constitucionalmente hablando) el régimen foral, lograrían el apoyo parlamentario de las autoridades locales vascas para gobernar. Constituye ésta una prueba más de la dificultad de consolidar en España un modelo de estado centralizado ${ }^{46}$. Pero después de estos primeros tiempos, los conservadores como Pastor Díaz o Cánovas, no tuvieron la menor duda de que la igualdad civil y política implicaba la unidad legislativa en todo el estado. En cualquier caso, los hombres de la generación de nuestro protagonista (e incluso los de la anterior, los que hicieron la Constitución de Cádiz), no tienen la menor duda de que España es un estado constituido por varios reinos, al modo de la antigua monarquía de la casa de Austria, diversos, pero formando un mismo país, concepto éste de país o nación plenamente decimonónico, al que obligan los requerimientos del liberalismo unificador, hijo de la llustración. De hecho, señala Alcalá, la permanencia de este tipo de peculiaridades, que alcanza al mismo carácter de la monarquía en España (hasta la guerra de 1808) pervivió con los Borbones y es prueba evidente de la escasa penetración del poder central en el entramado de la sociedad española en su conjunto. Por consiguiente y aunque la historia de Alcalá Galiano es una «historia de España», no se puede hablar ni en su caso ni en el de otros contemporáneos, de una historia nacionalista en el sentido en que tal concepto tendría durante los años cincuenta en las Ilamadas «historias generales»47. La Historia de Alcalá tiene más similitudes con los intentos de Guizot de rastrear los orígenes del gobierno representativo que con el objetivo de hacer una apología de las gestas de los bravos hispánicos de tiempos pasados. De este modo, su análisis busca siempre la pista que le lleve a la génesis y desarrollo de las ideas, las instituciones y los movimientos sociales, según veremos a continuación.

46 Rubio POBEs, C.: «El País Vasco y la implantación del estado liberal: centralización y unidad constitucionals: Revista de Estudios Politicos, n $^{\circ} 95$ (I-III-1997), p. 235. De la misma autora, Revolución y tradición. El Pás Vasco ante la Revolución liberal y la construcción del estado español (18081868), Madrid 1996. Sobre estas cuestiones, ORTIZ DE ORTUNo, J.M" «Las limitaciones de la revolución burguesa en España: el estado liberal y los fueros vascos»: Trienio, 13, (mayo de 1989), pp. 183-200.

47 JOVER, J.Má: La civilización..., pp. 140-191 y «Caracteres del nacionalismo español, 18541874m: Zona Abierta, 31 (IV-VI-1984), pp. 1-22; MORENO ALONSO, M.: Historiografía romántica española, Sevilla 1979, pp. 313-318. Este hecho es buen prueba de que el nacionalismo español no interesó a los conservadores hasta la guerra de África, y en cualquier caso, nunca fue un ingrediente policicamente muy sólido (ALVAREZ JUNCO, J.: «El nacionalismo español como mito movilizador. Cuatro guerras»: CRUZ, R y PeRez LeDESMA, M.: (eds.) Cultura y movilización en la España contemporánea, Madrid 1997, p. 47; y DE RrQuER, B.: «La débil nacionalización española en el siglo XIX»: Historia Social, $\mathrm{n}^{\circ} 20$ (1994), pp. 97-114. 
La concluyente mutación de España se produjo, por tanto, hacia finales del siglo XVIII, en ese proceso de revolución abortada del que hablábamos anteriormente. Presenta Alcalá la situación de nuestro país tras la guerra contra los franceses como algo nuevo, como algo diferente a todo lo anterior, aunque producto de ello. Así, no admite de ninguna manera las demandas de representación como una corriente tradicional en la historia de la Península. La búsqueda de referentes a la supuesta persistencia de una costumbre histórica de representación política le parece una quimera, «un tejido de sueños», como calificó la tarea de Martínez Marina en su Teoría de las Cortes. Sin embargo, no es ésta la interpretación dominante, puesto que, y por poner un ejemplo, algunos años después Angel Fernández de los Ríos, en su biografía de Olózaga, afirmaba entusiasmado que lo realmente antiguo y nacional en España era el sistema representativo, y que el absolutismo había llegado con las dinastías importadas que habían gobernado el país. Galiano mira al presente, y observa que la ordenación del régimen constitucional es plenamente contemporánea, hija de la herencia ilustrada y no de un pasado remoto, idealizado, probablemente más cercano al despotismo que a otra cosa, como comenta al hablar de los reinos hispánicos de la edad media, e incluso llega a poner como ejemplos de intolerancia y exclusivismo religioso la expulsión de los judíos por los Reyes Católicos. El cambio había comenzado a producirse en España con la penetración de ideas nuevas ya en el siglo XVIII, siglo en cuyo final nuestro país conoció una dura tensión entre la existencia de lo antiguo y la imparable llegada de lo moderno. De esta tensión comenzará a germinar la revolución, la cual se manifestó de muy diversas maneras, siendo una de ellas la lucha entre los constitucionales de Cádiz y la labor de zapa de la Iglesia y otra, el arraigo del tradicional apego del pueblo al rey, lo que reforzaba tremendamente su posición, enfrentado a las limitaciones a su poder que imponía la nueva Constitución. Esta contienda de ideas y tradiciones, inmersa en un marco de guerra contra las tropas extranjeras, repercutió de forma ostensible en el carácter de la autoridad del gobierno, en la misma esencia de la legitimidad del poder. La monarquía, ya desautorizada antes, perdió el prestigio de siglos en pocos años con la ayuda de Fernando VII, y los constitucionales aún no habían logrado hacer creer su importante papel a un país profundamente arraigado en estructuras tradicionales (como, según analiza Alcalá, puede verse por los conflictos de poder entre la Junta Central y las demás corporaciones). En este pátrafo nos describe de forma clara las consecuencias de todo ello:

«La insurrección de los españoles en su principio y fines justa, y hasta acertada, tuvo desde luego inconvenientes graves, y los preparó iguales o mayores para lo sucesivo. Con haberse creado gobiernos independientes en varias provincias, se aflojó de nuevo el nunca bien apretado lazo que unía entre sí a las vatias partes componentes de la monarquía española. Con un acto grande de desobediencia se convirtió ésta en costumbre, cosa más perjudicial en un país donde el gobierno, aun siendo despótico, solía ser imperfectamente obedecido. Con tener gobiernos 
nacidos de súbito cuyo origen era patente, y cuya vida venía por lo común a ser breve, siendo compuestos además de hombres conocidos poco antes como meros particulares, menguó y casi acabó la reverencia al ente moral llamado gobierno con perjuicio del bien público y de los mismos gobernados. La profusión con que las juntas repartían grados y honores, llegando algunas, y con especialidad la de Asturias, a nombrar generales hasta de la clase de capitanes, excitó muchas ambiciones, dejando para lo venidero ejemplos fatales por desgracia frecuentemente imitados. De haberse roto en pedazos el Estado, recibió su gobernación tal daño y desconcierto, que en muchos años no pudo recobrarse»48.

Vacíos de poder y ocasiones para los aventureros, he ahí la clave que explicará la difícil implantación en España del régimen liberal. La oportunidad que la guerra dio a elementos ajenos al poder político legítimo, como los guerrilleros (por la debilidad de aquél, claro está) introdujo el factor insurreccional en la política española, personificado unas veces en la milicia y otras en los militares profesionales. Esta insinuación parecía ser bastante común entre los observadores de los hechos, como ejemplo pongamos a Quintana, quien en su décima carta a Lord Holland (12-IV-1824), argumentó en esa misma línea y señaló la trascendencia que la forma en que se hizo la guerra, llamada de independencia, tuvo para el ejército, alimentando sus veleidades políticas y su indisciplina. El mismo fenómeno se dio, desde la perspectiva de Alcalá, en el ámbito de lo civil, pues los deseos de protagonismo individual unidos al tradicional particularismo de los españoles contribuyeron a deteriorar, aún más si tal cosa era posible, el muy endeble sustento del poder legítimo ${ }^{49}$. Junto a esto, y probablemente siendo su causa remota, se situaba una profunda crisis moral en España, provocada por la rápida muerte de la legitimidad tradicional, acelerada por Fernando VII y sus inconsecuencias, y por la carencia de otro sistema de valores lo suficientemente sólido como para sustituirla. Alcalá afirmaba que, por un

48 Alcala Galiano, A.: Historia de España..., vol. 6, p. 176. Sobre la complejidad de interpretaciones que ofrece la guerra a los ojos de cualquier interesado en el asunto, conviene la lectura del artículo de ALVAREZ JUNCO, J.: "La invención de la Guerra de la Independencia»: Claves de Razón Práctica, $\mathbf{n}^{\circ}$ 67, (nov. 1996), pp. 10-19, que reproduce uno anterior publicado en Studia Historica, vol. 12, (1994), pp. 75-99.

49 Alcalá Galiano insistió en repetidas ocasiones en las dificultades que el particularismo creaba a ta hora de integrar el estado liberal alrededor de las instituciones que le son propias. Especial interés tienen estas palabras escritas con motivo de los proyectos moderados de adminiscración local: «La idea de crear cuerpos que, con el nombre de Dipuraciones Provinciales, sean a las provincias a modo de lo que son a las ciudades, villas y aldeas los ayuntamientos, ha venido a España, como la mayor parte de las leyes políticas que hoy la rigen, de tierra extranjera, si bien con el espíritu de federalismo dominante en esta nuestra nación siempre mal unida, y desde la guerra de la independencia hasta ahora mucho más descuadernada que antes, aquí ha prendido, echando raíces un tanto hondas y recias, y dando frutos, si en algún caso buenos, facales en casi codas las ocasiones. Esto no obstante, la idea no es mala en si, y llevada a efecto por términos diferentes de los que se han usado, puede formar un eslabón de la cadena administrativa..", "De la institución, organización $y$ atribuciones de la cadena administzativa", en Revista de Madrid, I844, tomo II, p. 3. 
lado, la transformación en el mundo de las ideas hizo disminuir «...la superstición, y al separarse de ella, la religión perdió no poco", y por otro, los hábitos contraídos en la guerra y la época que la siguió habían menoscabado «...el respeto a las clases superiores, a lo cual el rey mismo había contribuido en los seis años que reinó con poder absoluto». Por tanto, la clave del fracaso de la revolución española hay que buscarla en esa imperfecta transmutación de valores: «El estado nuevo de la sociedad española, todavía no bien constituido, y cuyo origen viene de una mudanza, violenta en gran parte, pero no completa como la que disolvió a Francia casi en nuestros días, da muestras de las circunstancias pasadas en la situación presente, no sin que choquen las contradicciones entre las leyes, usos y costumbres, y aun entre pensamientos y afectos" ${ }^{30}$. Así, los incidentes aparecen como una catarsis retardada por el rey, de hecho la caracterización de Fernando VII como símbolo de la podredumbre de toda una época es común a todos los historiadores medianamente liberales, por muy monárquicos y conservadores que sean. El mismo Modesto Lafuente, hacedor de la más clásica historia patria, calificó su gobierno como «un reinado odioso hasta la repugnancia».

\section{CONCLUSIONES.}

Como puede deducirse, los principios morales y políticos del liberalismo español que sustentaron los pilares ideológicos del Trienio, basados en esquemas racionalistas, y por tanto ahistóricos, no habían sido lo suficientemente poderosos (precisamente por su carácter abstracto) como para servir de bagaje moral alternativo a una sociedad española deseosa de cambios. Así nació un generalizado sentimiento de decepción en el seno de los políticos y pensadores menos cercanos al progresismo, sentimiento que a la altura de 1844 (cuando Alcalá escribía su Historia) se encontraba plenamente asentado y que cooperó en gran medida a aquilatar esa imagen que los moderados querían dar de la era isabelina «síntesis de los tiempos». Se trataba, en cierto modo, de un deseo de dejar atrás el pasado, pero a la vez de hacer de ese pasado el fundamento del presente. La apariencia proyectada era, en gran medida, ficticia, por cuanto respondía a los intereses de aquéllos que presidian los gobiernos y se beneficiaban de la España moderada. De ahí que Jover haya caracterizado esta etapa y las intenciones de sus dirigentes como la potenciación de una imagen nacionalista de carácter retrospectivo, es decir, «aplicado a las necesidades y a la realidad polí-

so Ibidem, vol. 7, p. 599; en la misma línea: «De nuestras costumbres políticas», Obras..., vol. 2, p. 463. Los problemas derivados de la coexistencia de lo antiguo y lo moderno pueden verse muy claramente en el terreno de la terminologia política de la época, como han estudiado $\mathbf{M}^{\mathbf{a}}$ Cruz SEOANE en El primer lenguaje constitucional español, Madrid 1967, y VILAR, P.: en «Patria y nación en el vocabulario de la Guerra de la Independencia española»: Hidalgos, amotinados y guemilleros. Pueblo y poderes en la bistoria de España, Barcelona 1982, pp. 211-252. 


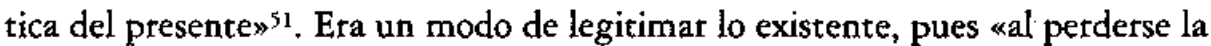
tradición, se abría el sentido de lo histórico», como dijera Díez del Corral. Y en ese círculo se halla inmerso el pensamiento de Alcalá Galiano, a quien la historia se aparece como un fruto de su análisis empírico del mundo, examen en el que se contiene pasado y futuro, dentro de una corriente intelectual en la que hay que incluir tanto a Burke como a Jovellanos, por poner un ejemplo español. El objetivo de este análisis no es otro que profundizar hasta el fondo en los acontecimientos políticos más recientes para descubrir las raíces de los comportamientos sociales del momento, para tratar de desentrañar las causas de la inestabilidad política nacional. Para otros autores más progresistas, éste hubiera sido el punto de partida para lanzar a la opinión pública regeneradores planes reformistas; para un moderado, sería la oportunidad de legitimar lo conseguido; para un moderado desengañado, como Antonio Alcalá Galiano, el análisis de la historia de España servía de acicate para señalar los peligros del extremismo político, un extremismo del que incluso él mismo fue objeto y del que sería, al final de su vida, sujeto.

"I JOVER, J. M..": La civilización española..., p. 172.

Hispania, LX/1, nám. 204 (2000) 289-314 